\title{
EKSPLORASI KEARIFAN LOKAL USAHATANI TEMBAKAU SRINTHIL DI LERENG GUNUNG SUMBING
}

\author{
Agus Ganjar Runtiko \\ Mahasiswa Doktoral Program Studi Penyuluhan dan \\ Komunikasi Pembangunan, Sekolah Pascasarjana \\ Universitas Gadjah Mada \\ Email: runtiko@gmail.com \\ F. Trisakti Haryadi \\ Program Studi Ilmu dan Industri Peternakan \\ Fakultas Peternakan Universitas Gadjah Mada \\ Roso Witjaksono \\ Departemen Sosial Ekonomi Pertanian \\ Fakultas Pertanian Universitas Gadjah Mada
}

\begin{abstract}
Srinthil is the name of the high quality tobacco commodity in Temanggung District. The quality of Srinthil tobacco is indicated by the higher price compared to other tobacco. Nevertheless, the emergence of Srinthil tobacco is unpredictable. Tobacco farmers believe that the emergence of Srinthil is influenced by at least four factors; siti (land), wiji (seeds), wanci (time), and wahyu (luck). The four factors considered influencing the emergence of Srinthil tobacco are sought by farmers. Tobacco farmer's effort to produce Srinthil resulting a variety of local wisdom. This study aims to describe the local wisdom constructed, believed, and practiced traditionally by tobacco farmers on the slopes of Mount Sumbing, Temanggung District. The method used in this study is qualitative with the case study approach, which focuses on the local wisdom of Srinthil tobacco farming. The study was conducted in Legoksari Village, Tlogomulyo sub-District in July-September 2017. Data collection was carried out by conducting indepth interviews and focus group discussions on 15 farmers, as well as five traditional leaders and village officials, participatory observation, and secondary data searches. The results showed that the local wisdom of tobacco farming consisted of three main categories: traditional rituals, house design, and work ethic. Aside from being an effort to search for Srinthil, the local wisdom of tobacco farming also serves as a medium for intergenerational value transmission, means of prayer to God, preservation of nature/environment, and maintenance of social cohesion.
\end{abstract}

Keywords: Farmer; Local wisdom; Srinthil; The slopes of Mt. Sumbing; Tobacco farming.

\section{ABSTRAK}

Srinthil merupakan nama komoditas tembakau khas Kabupaten Temanggung yang bermutu tinggi. Mutu tembakau Srinthil ditunjukkan oleh harganya yang mampu mencapai enam kali lipat harga komoditas tembakau biasa. Meskipun begitu, kemunculan tembakau Srinthil tidak dapat diprediksi. Petani tembakau meyakini bahwa kemunculan Srinthil dipengaruhi oleh setidaknya empat faktor; siti (tanah), wiji (benih), wanci (waktu tanam, rawat dan panen), dan wahyu (keberuntungan). Keempat faktor yang dianggap berpengaruh terhadap munculnya tembakau Srinthil dicari petani dengan melakukan berbagai upaya. Upaya petani tembakau mencari tembakau Srinthil menghasilkan berbagai 
kearifan lokal usahatani tembakau. Penelitian ini bertujuan untuk menggambarkan kearifan lokal yang dikonstruksi, diyakini, dan dilakukan secara turun temurun oleh masyarakat petani tembakau di lereng Gunung Sumbing, Kabupaten Temanggung. Metode yang digunakan dalam penelitian ini adalah kualitatif dengan pendekatan studi kasus, yang berfokus pada kearifan lokal usahatani tembakau Srinthil. Penelitian dilakukan di Desa Legoksari, Kecamatan Tlogomulyo pada rentang waktu antara bulan Juli-September 2017. Pengumpulan data dilakukan dengan melakukan wawancara mendalam dan focus group discussion terhadap 15 petani, serta lima tokoh adat dan perangkat desa, observasi partisipatif, dan penelusuran data sekunder berupa buku dan dokumen dari instansi terkait. Hasil penelitian menunjukkan bahwa kearifan lokal usahatani tembakau terdiri atas tiga kategori utama: ritual tradisional, desain rumah, dan etos kerja. Selain sebagai usaha untuk mencari Srinthil, kearifan lokal usahatani tembakau juga berfungsi sebagai media transmisi nilai antargenerasi, sarana doa kepada Tuhan, pelestarian alam/lingkungan, dan pemeliharaan kohesi sosial.

Kata kunci: Kearifan lokal; Lereng Gunung Sumbing; Petani; Usahatani tembakau; Srinthil.

\section{PENGANTAR}

Para pakar ilmu sosial menyadari bahwa sebuah komunitas atau masyarakat tertentu memiliki pengetahuan yang khas mengenai lingkungan alam di sekitarnya, dan menggunakannya untuk keberlangsungan hidup mereka. Pengetahuan ini bersifat lokal, dan seringkali hanya berlaku pada lingkungan setempat. Hefni (2008) menjelaskan bahwa pengetahuan khas ini secara umum dikembangkan melalui pengalaman (experimental learning) mengenai sebuah realitas, dan melalui proses pengamatan dan percobaan dalam rentang waktu yang cukup panjang, sehingga perkembangannya tidak secepat perkembangan pengetahuan modern.

Ada beberapa istilah yang digunakan untuk menyebut pengetahuan khas yang dimiliki sebuah komunitas atau masyarakat tertentu. Sebagian ahli menyebutnya sebagai pengetahuan lokal (local knowledge), namun ada juga yang menyebutnya sebagai indigenous knowledge, traditional knowledge, hingga traditional wisdom. Tulisan ini lebih memilih terminologi kearifan lokal atau local wisdom, yang dalam konteks budaya Indonesia dideskripsikan oleh Meliono (2011) sebagai sebuah bentuk ekspresi etnis, yang darinya orang melakukan aktivitas dan berperilaku, serta akhirnya, tindakan mereka menghasilkan karya-karya tertentu.

Kearifan lokal meliputi banyak aspek dalam kehidupan keseharian sebuah komunitas atau masyarakat tertentu sebagaimana dijelaskan oleh Koentjaraningrat (1964), yang meliputi sistem religius, sistem dan organisasi kemasyarakatan, sistem pengetahuan, sistem mata pencaharian hidup, serta sistem teknologi dan peralatan. Cakupan kearifan lokal tidak hanya terikat dengan nilai atau tradisi yang diwariskan dari leluhur, melainkan dapat berkembang dan bersinergi dengan pengetahuan serta inovasi baru, bersifat dinamis, serta mampu menyesuaikan perkembangan zaman. Misalnya saja, kearifan lokal dalam pembangunan rumah (Beddu et al., 2014), aksi demonstrasi (Darmastuti et al., 2016). Cakupan yang luas ini membedakan kearifan lokal dengan kearifan tradisional, yang menurut Wagiran (2012) lebih menekankan pada nilai tradisi yang ditanamkan melalui transmisi antargenerasi.

Beberapa nilai kearifan lokal dianggap bertentangan dengan nilai-nilai umum yang berlaku pada masyarakat luas, meskipun apabila ditelusuri lebih jauh, nilai kearifan lokal tersebut sebenarnya bersifat positif. Misalnya saja pada kasus kearifan lokal pengelolaan api lahan di hutan Mawas, Provinsi Kalimantan Tengah (Akbar, 2011), dan perburuan ikan paus oleh masyarakat nelayan Lamalera, Provinsi Nusa Tenggara Timur (Kurniasari dan Reswati, 2011).

Pada bidang pertanian, kearifan lokal tembakau sering dipandang negatif karena merusak kesehatan. Realitasnya di sentra usahatani tembakau, seperti Kabupaten Temanggung, 90 persen wilayahnya merupakan lahan tembakau (BAPPEDA Kabupaten Temanggung, 2016). Penyebabnya antara lain karena nilai ekonomi tembakau yang belum dapat digantikan oleh komoditas lain. 
Alamsyah (2011) misalnya, menemukan bahwa usahatani tembakau menyumbang lebih dari 70 persen pendapatan total petani di wilayah Kabupaten Temanggung.

Eksistensi tembakau di Kabupaten Temanggung berkaitan juga dengan kondisi geografis mayoritas wilayahnya yang berupa pegunungan, di mana sistem pertaniannya tadah hujan. Pada musim kemarau, tembakau jenis Voor-Oogst (VO) merupakan salah satu tanaman yang tumbuh subur karena kebutuhan airnya rendah.

Di Temanggung dikenal jenis tembakau yang memiliki kualitas tinggi dan karakternya memberikan aroma pada tembakau jenis lain, yang dinamakan Srinthil. Kadar nikotin Srinthil mencapai delapan persen dengan harga yang tinggi. Sentra tembakau yang dikenal sebagai penghasil Srinthil adalah Legoksari. Petani Legoksari mampu menghasilkan Srinthil dengan harga jual di atas 500.000 rupiah per kilogram, jauh di atas harga rata-rata tembakau biasa yang berkisar pada angka 100.000 rupiah per kilogram.

Tembakau Srinthil biasanya dihasilkan di lahan yang berada di lereng pegunungan. Lereng Gunung Sumbing merupakan wilayah di Kabupaten Temanggung yang paling banyak menghasilkan Srinthil dengan kualitas terbaik, yang berpusat di Desa Legoksari. Masyarakat Temanggung mengenal tembakau Legoksari dengan sebutan Mbako Nglamuk (Tembakau Lamuk), merujuk pada nama dusun di desa tersebut.

Penelitian ini bertujuan untuk melakukan eksplorasi kearifan lokal masyarakat petani tembakau di lereng Gunung Sumbing, yakni di Desa Legoksari, dalam usahatani tembakau meliputi: periode pratanam, periode tanam, periode panen, hingga periode pascapanen. Penelitian ini diharapkan dapat memberikan gambaran mengenai keadaan budaya salah satu masyarakat pertanian yang berhubungan dengan usahatani tembakau. Gambaran keadaan budaya masyarakat petani tembakau yang merupakan salah satu bentuk kearifan lokal dapat dijadikan sebagai salah satu sumber kebijakan pemerintah dalam membuat peraturan perundang-undangan yang berhubungan dengan usahatani tembakau.

Penelitian ini menggunakan metode deskriptif dengan data kualitatif, dengan strategi studi kasus. Data penelitian ini didapatkan melalui metode wawancara mendalam, pengamatan, dan studi dokumen. Wawancara dilakukan terhadap tokoh masyarakat, tokoh adat/sesepuh, dan beberapa petani tembakau warga Desa Legoksari. Pengamatan dilakukan secara partisipatif dengan terlibat dalam kegiatan kultural, dan kehidupan keseharian petani tembakau di Desa Legoksari. Studi dokumen digunakan sebagai pelengkap dalam analisis data; berupa penelitian pendahuluan, buku, data statistik, sumber tertulis, dan sumber audio-visual mengenai kearifan lokal usahatani tembakau.

Informan penelitian ini dipilih secara purposif. Creswell (2014) mengatakan bahwa pemilihan informan secara purposif akan mencontohkan kelompok masyarakat yang dapat memberikan informasi terbaik kepada peneliti tentang permasalahan riset yang sedang dipelajari agar informasi yang didapatkan peneliti mengenai kearifan lokal desa Legoksari merupakan yang terbaik, maka perlu ditentukan beberapa kriteria informan. Pertama, informan harus memiliki pengetahuan yang mendalam mengenai penduduk dan keadaan Desa Legoksari. Kedua, informan harus memahami adat istiadat dan budaya yang dipercaya serta dijalani oleh warga Desa Legoksari. Ketiga, informan yang memahami proses budidaya tembakau, serta pengolahan pascapanen.

Kualitas data yang dihasilkan dalam penelitian diuji menggunakan triangulasi sebagaimana yang disarankan Flick (2007), melalui berbagai metode pengumpulan data: membandingkan data wawancara, data pengamatan, dan data dokumen yang sahih. Selain itu, peneliti juga berusaha memperpanjang keberadaannya di lokasi penelitian untuk membandingkan data-data penelitian yang diperoleh dalam rentang waktu yang berbeda. 


\section{PEMBAHASAN}

Legoksari berada pada ketinggian antara 1.200-2.000 mdpl, dan merupakan salah satu desa terakhir sebelum masuk kawasan Perhutani di puncak Gunung Sumbing. Desa ini terletak di lereng Gunung Sumbing sebelah timur. Letak Desa Legoksari sangat menguntungkan untuk kegiatan usahatani tembakau. Penelitian Mamat et al. (2006) menunjukkan bahwa produktivitas tembakau yang ditanam pada lahan di lereng Gunung Sumbing bagian timur lebih baik dibandingkan dengan tanaman tembakau di lahan lain. Perbedaan produktivitas ini sangat erat kaitannya dengan sifat fotoperioditas tanaman tembakau dan memerlukan banyak sinar matahari. Intensitas sinar matahari yang tinggi biasanya didapatkan pada waktu pagi hari hingga menjelang siang, yang banyak diperoleh di lahan lereng timur Gunung Sumbing.

Desa Legoksari dibagi menjadi dua dusun, yakni Lamuk Legok dan Lamuk Gunung. Kisah penduduk setempat mengatakan bahwa sebenarnya nama Desa Legoksari adalah Lamuk yang artinya kabut atau awan, sedangkan arti Legoksari merupakan cekungan. Legoksari memang berupa cekungan di antara perbukitan di lereng Gunung Sumbing, dan akan diselimuti kabut ketika malam tiba. Kabut ini disebut warga dengan istilah bun. Apabila sinar matahari merupakan faktor utama produktivitas tembakau, maka bun merupakan faktor utama yang membentuk kualitas tembakau Srinthil.

Kombinasi geografis Legoksari yang berada di lereng timur Gunung Sumbing, serta terletak di bagian cekungan yang mendapatkan bun pembentuk kualitas Srinthil, menjadikan hampir seluruh penduduk desa memilih profesi sebagai petani tembakau. Kombinasi ini pula yang secara tidak langsung membentuk kearifan lokal, terutama berkaitan dengan kehidupan mereka sebagai masyarakat petani.

Kearifan lokal yang berkaitan dengan usahatani tembakau sebenarnya telah menjadi satu dengan jalinan budaya masyarakat setempat, sehingga sulit memisahkannya. Akan tetapi, secara garis besar, setidaknya ada tiga proses utama yang berperan dalam membentuk kearifan lokal usahatani tembakau, yaitu proses penanaman, proses panen, dan proses pascapanen. Artikel ini berusaha menggambarkannya dalam pembagian kearifan lokal ritual usahatani, rumah petani, dan gotong royong pascapanen.

\section{Ritual Usahatani}

Setiap bulan selalu ada kegiatan upacara tradisional yang diselenggarakan di Desa Legoksari, baik yang bersifat massal maupun personal. Upacara tradisional ini sebagian berkaitan dengan usahatani tembakau, sebagian lagi merupakan ritual yang bersifat umum; seperti Merti Dusun, Suran, Muludan, dan sebagainya. Upacara tradisiona yang bersifat massal biasanya melibatkan banyak orang, dengan biaya yang ditanggung bersama secara gotong royong. Bentuk gotong royong pembiayaan kegiatan upacara tradisional di Legoksari dikenal dengan sebutan Sewu Selawe, yakni kewajiban petani menyisihkan 2,5 persen hasil panen tembakaunya untuk keperluan kegiatan sosial kemasyarakatan. Uang tersebut disetorkan kepada ketua kelompok tani atau ketua RT, yang kemudian dihimpun oleh perangkat desa. Jumlah akumulasi pembiayaan Sewu Selawe ini biasanya sudah memadai untuk kegiatan upacara tradisional massal selama setahun. Seandainya jumlah dana masih kurang, akan ada penarikan yang dilakukan ke setiap rumah tangga dengan besar iuran yang disepakati bersama.

Upacara tradisional yang bersifat personal hanya melibatkan sedikit orang, dan biayanya ditanggung oleh pribadi warga. Jumlah orang yang diundang dalam upacara personal tergantung keperluan dan kemampuan penyelenggara, namun biasanya tidak lebih dari 30 orang. Ada juga beberapa upacara personal yang hanya dilakukan sendirian oleh petani di ladang tembakau. Perlengkapan atau $u b o$ rampe upacara personal sepadan dengan upacara massal, namun dalam jumlah yang lebih sedikit.

Usahatani tembakau memiliki setidaknya tujuh rangkaian ritual upacara tradisional khusus. Masing-masing ritual tersebut berisikan pesan-pesan simbolis dan doa kepada Tuhan agar usahatani tembakau di Legoksari 
diberi keselamatan. Rangkaian ritual upacara tersebut juga berfungsi sebagai pengikat kebersamaan petani yang selama musim tembakau disibukkan dengan usahatani masing-masing, sehingga tidak sempat berinteraksi sesama warga. Tujuh rangkaian ritual itu terdiri atas Momongi Macul, Nyecel, Lekas, Among Tebal, Lekas Amek, Tungguk, dan Nyampar Bun.

Ritual upacara tradisional pertama yang dilakukan dalam usahatani tembakau adalah Momongi Macul. Ritual ini dibuat secara massal di tingkat desa, akan tetapi petani yang mendapatkan hasil panen berlebih biasanya mengulang pelaksanaan ritual Momongi Macul secara personal, disatukan dengan upacara tradisional dalam hajatan lain, seperti khitanan atau pernikahan. Kelengkapan atau ubo rampe upacara ini antara lain Golong Agung, yaitu nasi yang di atasnya diberi telur dadar. Golong Agung merupakan simbolisasi dua unsur, yakni bahan nasi yang mewakili tanah, dan bahan telur yang mewakili tanaman. Kedua bahan tersebut akan terasa lebih enak apabila dimakan bersama-sama, demikian pula dunia pertanian yang membutuhkan unsur tanah dan tanaman secara berimbang agar memberikan penghasilan bagi petani.

Simbolisasi lain dalam ritual upacara tradisional Momongi Macul berupa empat gelas dan satu teko yang berisi kopi. Kopi diberi gula, kemudian dituangi air panas, tetapi tidak diaduk sehingga masih terasa pahit. Kopi yang masih terasa pahit ini selanjutnya dituang ke dalam gelas untuk diminum. Pemangku adat kemudian memanjatkan doa-doa yang diiringi pengadukan air kopi dan gula di dalam teko. Air kopi yang sudah berasa manis kembali dituang ke setiap gelas dan diminum bersama. Makna simbolisasi ini adalah sebuah pesan bahwa kehidupan di dunia pertanian biasanya akan diawali dengan kepahitan, kemudian diakhiri dengan kebahagiaan, sehingga petani harus selalu bersabar dan tawakal. Momongi Macul biasanya diselenggarakan setelah musim tembakau berakhir menjelang musim tanam tahun berikutnya.

Urutan ritual upacara tradisional kedua adalah Nyecel. Ubo rampe atau perlengkapan ritual Nyecel antara lain sego bakar (nasi bakar) dengan porsi kecil. Di atas sego bakar itu ditancapkan lidi yang berisikan terasi, bawang merah, bawang putih, dan cabai merah di bagian paling atas. Masing-masing ubo rampe ini merupakan simbolisasi petuah. Sego bakar merupakan simbolisasi keyakinan, ojo ngenes (jangan khawatir) terhadap budidaya tembakau yang hendak dilakukan. Terasi aromanya dalam bahasa Jawa disebut banger merupakan simbolisasi penetralisir kekuatan jahat yang mengganggu usahatani tembakau. Bawang putih aromanya disebut sengir yang bermakna semingkir atau menyingkirkan hama agar berpindah dari ladang tembakau. Bawang merah (brambang) beraroma pedas yang bermakna mempertimbangkan segala sesuatu dari sisi baik dan buruknya secara matang. Cabai beraroma panas yang bermakna semangat untuk bekerja di ladang pertanian tembakau.

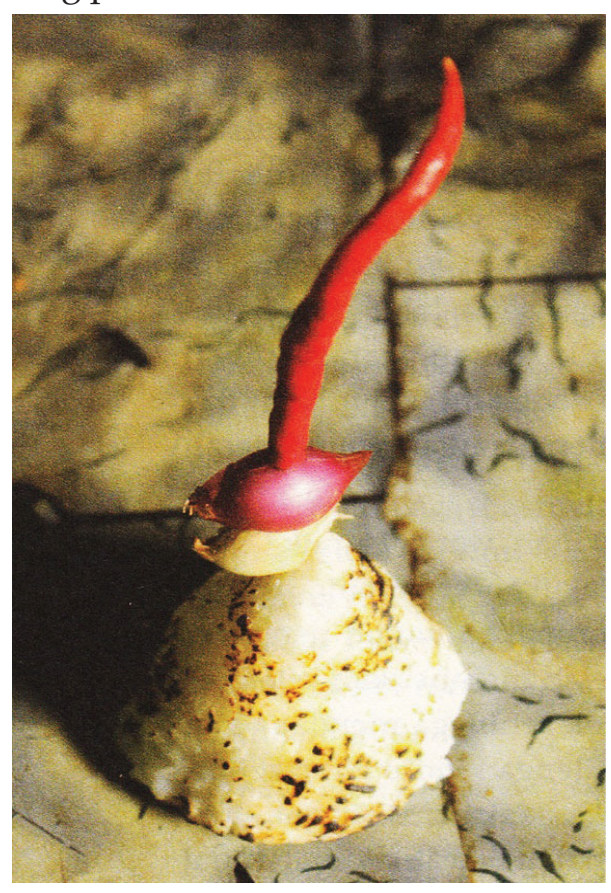

Gambar 1

Sego Bakar dalam Ritual Nyecel (Sumber: Laily,2016)

Nyecel biasanya diselenggarakan di lahan pertanian setelah musim tembakau pada bulan Suro (Muharram), dan dilakukan sendiri oleh petani tanpa mengundang siapapun. Tujuan ritual Nyecel adalah sebagai bentuk persiapan pengolahan lahan untuk ditanami tembakau, 
sebagaimana dikatakan oleh salah seorang informan:

"Bahwa ketika kita akan mengolah lahan, pertama harus ada ritual, itu namanya Nyecel. Jadi secara filosofi kita kulanuwun (permisi). Kita kulanuwun dengan bumi, karena sudah memberikan berkah dari tanaman-tanaman yang tumbuh dari bumi ini, kemudian kita mengucapkan terima kasih..." (Stp, 22 Juli 2017).

Ritual Nyecel dilanjutkan dengan ritual Lekas atau Nglekasi. Ritual ini dilakukan di kebun tembakau sebagai tanda petani akan memulai menanam tembakaunya. Biasanya ritual lekas nandur diadakan sebulan sebelum penanaman. Petani memanjatkan doa mengharap keselamatan dan kelancaran dalam membudidayakan tanaman tembakau. Ritual Nglekasi dan ritual Nyecel memiliki ubo rampe yang sama, hanya berbeda tujuan. Ritual Nglekasi bertujuan untuk memulai tanam tembakau, sedangkan ritual Nyecel bertujuan memulai pengolahan lahan dalam satu tahun.

Ritual berikutnya adalah Among Tebal, yakni ritual yang dilakukan pada awal tanam tembakau. Ritual Among Tebal merupakan upacara tradisional yang bersifat massal dan paling meriah dibandingkan upacara tradisional tembakau lainnya. Ubo rampe yang disajikan dalam ritual Among Tebal bermacam-macam, tetapi yang paling utama adalah Tumpeng Ireng atau olahan nasi yang berbentuk kerucut dan berwarna kehitaman. Selain Tumpeng Ireng, ada beberapa tumpeng lain yang disajikan; seperti Tumpeng Putih, Tumpeng Kuning, Tumpeng Megono, Tumpeng Blorok, Tumpeng Robyong, dan Tumpeng Tolak. Masing-masing tumpeng tersebut memiliki makna mengenai doa pengharapan warga desa petani tembakau.

Tumpeng Ireng atau tumpeng hitam yang disajikan dalam ritual Nyecel ini sejatinya berwarna ungu kehitaman, terbuat dari bahan beras ketan hitam yang dicampur dengan beras putih. Masyarakat Legoksari menyebutnya Tumpeng Ireng karena adanya kandungan beras ketan hitam tersebut. Warna ungu dalam Tumpeng Ireng ini bermakna wungu dalam bahasa Jawa halus berarti bangun. Simbolisasi tumpeng ungu adalah sebuah petuah bahwa sebaik-baiknya petani yang istirahat, lebih baik lagi petani yang bangun dan bekerja keras. Nasi tumpeng ini juga merupakan bentuk penghormatan terhadap hidangan kesukaan Ki Ageng Makukuhan, orang yang dipercaya membawa benih dan melakukan budidaya tembakau pertama kali di Temanggung pada abad ke-16.

Tumpeng Putih dimaksudkan sebagai pengharapan akan keselamatan warga, selain merupakan simbolisasi kesucian hati. Kesucian hati yang dimiliki petani akan membawa kesungguhan dalam melakukan usahatani tembakau. Tumpeng Kuning merupakan simbolisasi pengharapan agar tanaman tembakau tetap lestari di Desa Legoksari serta dikaruniai cuaca yang terang agar tembakau yang dibudidayakan tumbuh subur. Tumpeng Kuning juga bermakna kemalasan atau keadaan istirahat, sebuah kondisi manusiawi yang mengiringi usahatani tembakau. Istirahat yang dilakukan petani merupakan upaya pengumpulan energi untuk melakukan pekerjaan usahatani tembakau yang lebih semangat. Adapun Tumpeng Megono dibuat dengan mencampur beras atau nasi dengan sayuran dan lauk-pauk. Tumpeng Megono ini merupakan simbolisasi pengharapan agar petani tembakau yang berbeda-beda karakter tetap menjaga persatuan demi kelestarian tembakau. Tumpeng Megono juga menjadi simbolisasi berbagai perasaan yang menjadi satu dalam usahatani tembakau. Tumpeng Blorok dimaksudkan sebagai simbolisasi permohonan kekuatan perlindungan Tuhan kepada para petani tembakau, adapun Tumpeng Robyong merupakan bentuk simbolisasi kemakmuran. Hasil penjualan tanaman tembakau diharapkan memberikan penghasilan yang menyejahterakan dan memakmurkan petani tembakau. Tumpeng Tolak merupakan perlambang permohonan kepada Tuhan agar menolak segala gangguan dalam usahatani tembakau. Gangguan yang dimaksud dapat berasal dari hama, penyakit tembakau, hingga kebijakan pemerintah atau kelompok masyarakat lainnya yang dapat mengancam kelestarian usahatani tembakau. 
Ritual berikutnya adalah Lekas Amek. Ubo rampe ritual Lekas Amek ini sama dengan ritual Nglekasi atau ritual Nyecel. Perbedaan antara ketiga ritual tersebut terletak pada waktu dan tujuan pelaksanaan. Ritual Lekas Amek dilaksanakan menjelang panen tembakau, dengan tujuan sebagai pengharapan agar panen tembakau dapat menghasilkan panen yang bagus dan harganya tinggi.

Ritual Lekas Amek dilanjutkan ritual khas tembakau selanjutnya yang disebut Tungguk. Ritual ini dilakukan pada Mangsa Katelu dalam perhitungan Pranata Mangsa Jawa, yakni saat pertengahan petik tembakau, dan dianjurkan dilakukan pada hari, pasaran, dan neptu yang baik. Ritual Tungguk dilaksanakan dengan membawa berbagai sesaji seperti ingkung, juadah pasar, kembang, pisang, wajik, rokok, wedang asem, dan gula-kelapa. Semua makanan tersebut dibawa ke lahan kemudian diberikan kepada siapapun yang hendak panen tembakau yang dijumpai di jalan. Tujuan ritual Tungguk itu diistilahkan makani cah angon, sebagai bentuk syukur karena telah diberi keselamatan sejak awal menanam tembakau hingga hampir panen.

Ritual terakhir yang dilakukan petani dalam rangka usahatani tembakau adalah Nyampar Bun. Ritual ini sebagai bentuk tasyakuran usahatani, dari proses tanam, panen, pengolahan, sampai akhir sudah terjual tembakaunya. Nyampar Bun ini waktunya kadang-kadang disamakan dengan ritual awal usahatani tembakau, Momongi Macul, untuk periode tahun berikutnya.

Petani tembakau yang mengadakan ritual tradisional, kemudian mengundang tetangga, biasanya dalamjumlah ganjil. Filosofiundangan ganjil adalah sebagai bilangan yang ketika dibagi masih memiliki sisa, maknanya petani berharap mendapatkan sisa atau untung dari usahatani tembakau mereka. Jumlah tertentu undangan juga mengandung makna bagi petani tembakau, misalnya undangan tujuh orang, atau kalau dalam bahasa Jawa disebut pitu sebagai pengharapan mendapat pitulungan (pertolongan). Petani dapat mengundang sebelas orang, atau disebut sewelas dalam bahasa Jawa, sebagai simbolisasi pengharapan mendapat kawelasan (belas kasih). Secara umum petani tembakau Legoksari berprinsip agar siapapun yang mencium aroma masakan tasyakuran ikut merasakan nikmatnya.

Budaya Jawa memang banyak menggunakan simbolisasi dalam setiap upacara atau ritual yang berisi ajaran normatif mengenai relasi sesama manusia, relasi manusia dengan alam, dan relasi manusia dengan Tuhan. Herawati (2007) melihat relasi dalam simbolisasi budaya Jawa ini memiliki arah hubungan vertikal dan horisontal, yang merujuk pada hubungan manusia dengan Tuhan atau makhluk supranatural di mana sebagai tempat untuk memohon keselamatan, dan hubungan antarmanusia dalam hidup bermasyarakat untuk menjaga keharmonisan dan ketentraman.

Simbolisasi dalam budaya Jawa pada dasarnya merupakan bentuk kearifan lokal komunikasi dalam kerangka transmisi nilai antargenerasi, dengan tujuan akhir sebagai upaya masyarakat mempertahankan konsep budayanya; berupa fungsi, satuan, batas, bentuk, lingkungan, hubungan, proses, masukan, keluaran, dan pertukaran (Soeleman, 1988, dalam Sartini, 2009). Tindakan-tindakan simbolik dalam sebuah masyarakat budaya bermaksud menyederhanakan sesuatu yang memiliki makna lebih rumit. Bentuk penyederhanaan ini kemudian memerlukan pemaknaan ulang melalui proses interpretasi atau komunikasi terhadapnya.

Simbol sebagai sebuah bentuk komunikasi pada dasarnya digunakan agar pesan lebih mudah dipahami, yang kemudian memiliki fungsi "penghasut" tindakan sosial (Turner, 1967, dalam Haryanto, 2013). Simbol sebagai "penghasut" tindakan sosial memiliki peran melakukan transformasi perilaku sosial masyarakat penggunanya. Masalah utama dalam peranan simbol dalam transformasi perilaku sosial adalah sifatnya yang multitafsir karena sifat pesan simbol umumnya tersembunyi dan tidak jelas. Pemaknaan terhadap simbol pada akhirnya bersandar pada pengalaman budaya, sehingga perlu pemahaman yang didasarkan pada pengetahuan budaya atau kearifan lokal. Dalam konteks usahatani tembakau, pemaknaan terhadap lahan merupakan sebuah konstruksi simbolis (Yenrizal et al., 2015). Sawah tidak 
lagi dianggap sebagai benda mati, melainkan memiliki makna tersendiri, yaitu makna kesejahteraan, makna kekuasaan, dan makna identitas. Pemaknaan sawah berbasis kearifan lokal pada akhirnya dapat memperbaiki produktivitas lahan dan tanaman, terutama penataan lahan, penggunaan bahan organic baik pupuk kandang, dan sisa tanaman (Kasno, 2018).

Generasi penerus petani tembakau sebagai muara transmisi pengetahuan kearifan lokal hendaknya memiliki pengetahuan budaya yang cukup sebagai sandaran pemaknaan terhadap simbolisasi budaya dalam ritual usahatani tembakau. Kurangnya pengetahuan budaya generasi muda petani dapat menyebabkan pendangkalan makna pesan adiluhung dalam simbolisasi ritual usahatani tembakau. Kekuatiran Haryanto (2013) dalam penelitiannya mengenai dunia simbol Jawa perlu mendapat perhatian, yakni pemaknaan yang tidak sekedar mengalami pendangkalan, tetapi justru bertentangan dengan misi utama simbol budaya.

Simbolisasi yang terkandung dalam ritual usahatani tembakau sekaligus sebagai upaya transmisi nilai, baik secara personal maupun komunal. Secara personal, ritual tersebut menjadikan orang tua memiliki peranan dalam transmisi nilai, di mana menurut Matualage (2011) peranan orangtua merupakan sistem pembelajaran sosial yang paling efektif. Sedangkan secara komunal, peran ritual adalah membangun sistem kepercayaan yang menurut Saleh (2014) merupakan sebuah pengontrol perilaku yang sangat ampuh.

\section{Rumah Petani}

Bangunan fisik selalu menandai tingkat perkembangan kehidupan manusia, sehingga setiap bangunan sarat dengan nilai intrinsik tentang kearifan lokal (Ahimsa-Putra, 2008, dalam Djono dkk., 2012). Rumah sebagai salah satu bentuk bangunan fisik, dengan demikian merupakan bentuk manifestasi kearifan lokal komunitas atau masyarakat tertentu.

Rumah petani tembakau Legoksari ratarata menggunakan prinsip desain fungsional, yakni sebagai tempat tinggal sekaligus sarana pendukung usahatani tembakau. Tidak ada hiasan atau dekorasi rumah yang berlebihan kecuali hanya sebatas foto-foto, lukisan dan beberapa perabot. Bentuk rumah mereka juga tidak mengacu gaya tradisional Jawa berupa rumah joglo atau memiliki pendhapa. Mereka lebih memilih membangun rumah dengan gaya modern. Kebanyakan petani tembakau Legoksari memang mulai membangun rumah mereka pada tahun 1970-an, ketika harga tembakau sangat tinggi. Pembanguan rumah mereka terus berlanjut secara bertahap untuk menyesuaikan dengan jumlah penghuni yang saat ini sudah mencapai generasi ketiga dalam keluarga.

Pondasi rumah petani tembakau di Legoksari rata-rata cukup tinggi dan kuat untuk menopang bangunan, sebagai adaptasi terhadap keadaan geografis tanah pegunungan yang tidak rata. Pondasi yang tinggi dan kuat diperlukan, sehingga petani dapat membangun dak beton di bagian atas rumah sebagai sarana usahatani tembakau. Sebagian petani juga memanfaatkan pondasi tersebut untuk membangun rumah berlantai dua atau lebih. Konstruksi rumah petani Legoksari biasanya akan membuat orang yang baru pertama kali berkunjung merasa heran dengan keadaan desa. Suasana Legoksari lebih mirip perkotaan alih-alih sebuah desa terakhir sebelum memasuki puncak Gunung Sumbing.

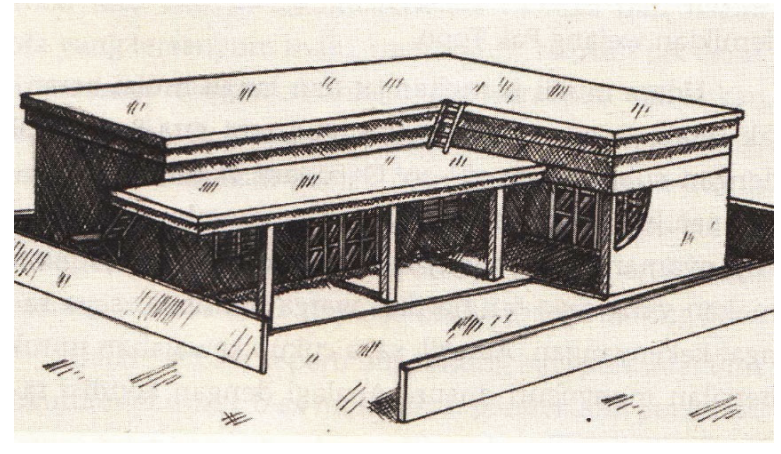

Gambar 2

Ilustrasi Rumah Petani Legoksari (Sumber: Laily, 2016)

Keadaan ekonomi petani tembakau Desa Legoksari dapat dikatakan lebih baik dibandingkan petani tembakau lain di desa sekitarnya, sehingga mampu membangun rumah yang cukup bagus. Petani juga membutuhkan 
konstruksi rumah yang kuat sebagai sarana usahatani tembakau, sebagaimana dikatakan oleh salah satu informan:

"Desain (rumahnya) itu ya macem-macem, tapi pada pokoknya itu didak, untuk njemur. Soale paling sekeca njemur niku lak teng nggriyane piyambak. Nek misale udan langsung dientas (Desain (rumahnya) itu ya macam-macam, tapi pada pokoknya itu ditingkat, untuk njemur. Soalnya paling enak menjemur tembakau di rumah sendiri. Seandainya hujan bisa langsung diangkat)" (Sbd, 29 September 2016)

Bagian atas rumah petani tembakau Legoksari secara umum didesain terbuka tanpa atap seperti ditampilkan pada Gambar 2, yang biasanya digunakan untuk menjemur rajangan tembakau ketika musim panen tiba. Menjemur tembakau di rumah sendiri akan lebih memudahkan pemindahan rigen seandainya tibatiba hujan. Petani juga tidak perlu menyewa lahan sebagai sarana jemur tembakau.

PetaniLegoksari lebih memilih menjemur di rumah sendiri karena didorong oleh keyakinan mereka tentang bun (kabut lokal) yang dianggap merupakan faktor utama pembentuk tembakau Srinthil. Beberapa petani tembakau menuturkan tentang penelitian yang pernah dilakukan mengenai budidaya tembakau penghasil Srinthil. Sampel tembakau, tanah, hingga bun dibawa ke Amerika untuk dilihat kandungan senyawa kimianya. Penelitian tersebut berakhir dengan kesimpulan bahwa komoditas Srinthil terikat secara geografis pada wilayah-wilayah tertentu, serta tidak dapat diduplikasi di wilayah lain. Tembakau Srinthil memang harus ditanam, dipanen, dan diolah di Legoksari, seperti itulah keyakinan petani.

Penjemuran tembakau di rumah petani juga berkaitan dengan kearifan lokal prakiraan cuaca. Petani tembakau rupanya memiliki ilmu titen (berdasar pengalaman) tentang peramalan turunnya hujan dari arah hembusan angin. Peramalan turunnya hujan ini biasanya dilakukan saat petani hendak melakukan proses ngemot (mengemas tembakau dalam keranjang). Proses ngemot dilakukan malam hari ketika bun turun agar tembakau yang telah selesai dijemur dalam keadaan ayem (lemas). Tembakau yang tidak ayem akan rusak ketika dimasukkan keranjang. Informan Rbn (33), salah satu perangkat Desa Legoksari yang juga merupakan petani penghasil Srinthil mengatakan bahwa ilmu titen petani didasarkan pada arah angin malam hari. Apabila angin bertiup dari arah barat biasanya tidak disertai bun, sehingga petani harus menunggu lebih lama sampai angin berubah arah. Apabila angin bertiup dari arah utara atau selatan, petani harus bersiap-siap mengemasi rigen karena biasanya akan segera turun hujan. Angin yang paling ditunggu petani adalah yang berasal dari arah timur, yang biasanya membawa bun. Proses menunggu datangnya angin dari timur ini sering memerlukan waktu yang cukup lama, kadangkadang hingga dinihari.

Fungsi rumah petani Legoksari tidak hanya terbatas sebagai sarana menjemur rajangan tembakau. Rumah mereka juga dijadikan tempat pengolahan tembakau; seperti ngimbu (pemeraman), ngrajang (perajangan), nggulungi (penataan hasil penjemuran), dan ngemot (pengemasan). Para petani tembakau juga menyimpan hasil panenan mereka dalam keranjang-keranjang yang ditata secara rapi dalam sebuah ruangan yang dianggap aman. Desain rumah petani pada akhirnya juga harus menyesuaikan dengan fungsi-fungsi tersebut.

Salah satu proses pengolahan tembakau yang membutuhkan penyesuaian desain rumah adalah ngimbu (memeram daun tembakau). Rumah-rumah di Legoksari memiliki banyak pintu dan ventilasi, yang digunakan untuk mengendalikan angin yang masuk ke dalam rumah.

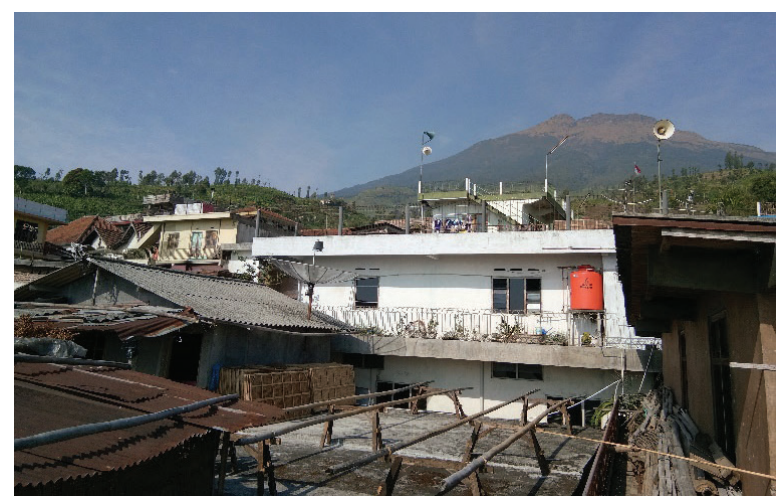

Gambar 3

Rumah-rumah di Desa Legoksari (Sumber: Dokumentasi Lokasi Penelitian) 
Ruang pemeraman biasanya memiliki ventilasi berupa kaca nako, pintu, lubang angin di atas jendela, atau lubang angin di bawah pintu. Ventilasi diusahakan tidak bersifat permanen, artinya dapat dibuka dan ditutup sesuai keinginan pemilik rumah, sehingga memudahkan proses buka-tutup ketika suhu ruangan terlalu panas atau terlalu dingin. Suhu ruang pemeraman yang terlalu panas, terlalu dingin, atau terlalu berangin mengurangi kualitas tembakau yang diperam. Rumah yang didesain dengan banyak pintu mempermudah akses ke berbagai ruangan, sehingga membuat petani leluasa ketika melakukan rangkaian proses pengolahan tembakau secara simultan, misalnya, ketika petani harus memeriksa tingkat kelembaban suhu pemeraman yang bersamaan dengan keharusan membalik jemuran tembakau di bagian atas rumah.

Jarak antarrumah warga di Desa Legoksari sangat dekat, rata-rata hanya dipisahkan oleh gang kecil yang lebarnya sekitar satu meter. Sebagian rumah mereka bahkan berhimpitan. Hampir tidak ada rumah yang memiliki pekarangan luas seperti umumnya rumah di pedesaan Jawa. Wilayah Desa Legoksari memang tidak terlalu luas, sehingga warga tidak banyak memiliki pilihan lahan untuk membangun rumah. Struktur sebagian besar tanah di Legoksari tidak rata, labil, dan berada pada tingkat kemiringan di atas 60 derajat, menjadikannya sangat sulit dijadikan kawasan tempat tinggal. Rumah-rumah yang berdekatan biasanya dihuni warga yang masih memiliki hubungan keluarga, menempati lahan milik keluarga, dan saling memaklumi adanya gangguan terhadap ruang privasi mereka. Kedekatan jarak antarrumah juga mempermudah kegiatan usahatani tembakau, misalnya saja kemudahan komunikasi antartetangga yang memberi peringatan turunnya hujan ketika penjemuran tembakau.

Desain rumah petani tembakau yang berorientasi nilai modern mungkin dimaknai sebagian kalangan sebagai degradasi budaya Jawa dalam kehidupan sehari-hari. Penelitian ini melihat desain rumah ini sebagai bagian dari kearifan lokal petani tembakau, mengingat mereka masih melaksanakan praktek budaya
Jawa dalam ritual dan upacara-upacara adat. Petani tembakau ini bukan kelompok masyarakat yang enggan mempraktikkan budaya adiluhung dalam kehidupan seharihari karena alasan yang disebutkan Djono et al. (2012), antara lain kurang praktisnya kebudayaan Jawa serta banyaknya aturan dan ritual yang mahal.

\section{Gotong Royong Setelah Panen}

Gotong royong merupakan salah satu bentuk kelembagaan serta tata nilai asli yang dimiliki oleh bangsa Indonesia. Buktinya, gotong royong memiliki berbagai sebutan dalam bahasa-bahasa lokal di Indonesia (Pranadji, 2009); seperti semangat holo pis kuntul baris di Jawa, pela gandhong di Maluku, dalihan-non-tolu di Tapanuli, dan mapalus di masyarakat Minahasa. Seiring berjalannya waktu, tata nilai gotong royong dianggap mulai luntur di masyarakat. Modernisasi dianggap sebagai salah satu faktor penghancur tata nilai asli gotong royong (Dharmawan, 2007), dan menggantinya dengan nilai-nilai modern seperti sistem upah, transaksi, dan hal-hal lain yang berhubungan dengan uang sebagai sebuah nilai tukar yang disepakati bersama, sekaligus representasi kapitalisme. Menurunnya kadar kegiatan gotong royong dalam masyarakat menurut Hidayati (2016) berkitan erat dengan memudarnya kearifan lokal, terutama berkaitan dengan rasa kepemilikan bersama.

Pada awalnya, gotong royong identik dengan masyarakat di pedesaan yang sarat dengan nilai-nilai paguyuban, dan menjunjung tinggi nilai tradisi. Seiring berjalannya waktu, banyak masyarakat pedesaan yang mengalami penurunan semangat gotong royong. Sebagian masyarakat pedesaan lain memodifikasi semangat gotong royong mereka untuk menyesuaikan dengan nilai modern dari dunia luar, salah satunya di Legoksari.

Masyarakat Legoksari mengenal istilah royongan untuk menyebut kegiatan mengerjakan sebuah pekerjaan secara bersama-sama dengan sukarela dan tanpa upah. Apabila pekerjaan tersebut ditujukan untuk membantu individu warga, biasanya akan didahului 
dengan nyambat; yakni sebuah bentuk undangan royongan kepada warga lain. Warga yang nyambat biasanya cukup menyediakan makanan dan minuman bagi warga lain yang royongan.

Banyak aspek kehidupan warga Legoksari yang melibatkan royongan, misalnya acara pernikahan, kematian, atau membangun rumah, namun yang setiap tahun dilakukan oleh seluruh masyarakat adalah royongan yang berkaitan dengan usahatani tembakau. Royongan dalam usahatani tembakau dibagi menjadi dua, masa sebelum panen, dan masa setelah panen. Masa sebelum panen meliputi masa tanam hingga tembakau siap panen. Petani tembakau membutuhkan cukup banyak tenaga kerja pada periode ini, tetapi masa sebelum panen yang cukup panjang menjadikan mereka biasanya tidak nyambat kepada warga lain. Petani yang memiliki lahan sempit akan memilih mengerjakan sendiri ladangnya, sedangkan petani yang memiliki lahan lebih luas akan mendatangkan buruh tani dari wilayah di sekitar Legoksari.

Masa setelah panen tembakau menjadi waktu yang sangat sibuk bagi petani tembakau. Mereka harus melakukan pemetikan daun (amek), sortasi (milihi), penataan daun (nglempeti), pemeraman (ngimbu), perajangan (ngrajang), penataan rajangan (nganjang), penjemuran (ngeme), penataan hasil penjemuran (nggulungi), hingga pengemasan (ngemot) dalam jangka waktu yang pendek. Hujan yang sewaktu-waktu turun menjadi penyebab pendeknya waktu pengolahan tembakau. Jenis tembakau yang ditanam petani Legoksari sangat sensitif terhadap hujan, membuat kualitasnya menurun, dan mengurangi keuntungan petani.

Jangka waktu pengolahan tembakau pada masasetelah panenyangpendekmengakibatkan jumlah tenaga kerja yang dibutuhkan dalam usahatani tembakau meningkat dibandingkan dengan masa sebelum panen. Tenaga kerja yang melakukan penanaman dan perawatan tembakau pada masa sebelum panen biasanya tidak lagi mencukupi, sehingga sistem royongan dalam skala terbatas dilakukan. Petani di Desa Legoksari pada umumnya tidak menerapkan sistem royongan secara massal. Mereka menyadari bahwa hampir seluruh warga Legoksari memiliki kesibukan yang sama di musim tembakau, dan hampir tidak ada yang menganggur. Para petani merasa sungkan apabila harus meminta bantuan kepada warga lain yang sedang sama-sama sibuk, sehingga mereka merasa cukup dengan melibatkan keluarga dan tetangga dekat saja.

Royongan yang melibatkan keluarga atau tetangga biasanya tidak diiringi nyambat. Keluarga dan tetangga yang tidak sedang mengolah tembakau otomatis akan dengan sukarela membantu, setelah mendapatkan informasi adanya royongan dari pedagang sayur keliling. Pedagang sayur menjadi pusat informasi royongan karena adanya kebiasaan untuk memasak lebih banyak ketika sebuah rumah hendak menyelenggarakannya. Keluarga dan tetangga yang memastikan kebenaran informasi ini, kemudian menyebarkannya dengan sistem gethok tular (dari mulut ke mulut).

Di antara seluruh proses pengolahan tembakau, hanya aktivitas amek dan ngimbu yang biasanya tidak melibatkan royongan. Aktivitas amek dan ngimbu biasanya dilakukan oleh petani pemilik lahan dan buruh tani upahan. Adapun milihi dilakukan oleh kaum perempuan keluarga petani pemilik lahan, karena dianggap memiliki ketelitian. Aktivitas milihi dilakukan dengan memisahkan daun yang layak dirajang dengan yang tidak layak, mengulang proses serupa ketika amek di ladang.

Perempuan keluarga petani tembakau banyak terlibat juga dalam aktivitas nglempeti dan nganjang. Aktivitas nglempeti dan nganjang termasuk kegiatan yang ringan tapi membutuhkan ketelatenan, sehingga bentuk gulungan daun tembakau dan bentuk anjangan di rigen (media penjemuran) bagus. Aktivitas nglempeti biasanya diselenggarakan sore hari hingga malam, sedangkan nganjang dilakukan setelah ibadah salat Subuh setelah selesai ngrajang.

Ngrajang merupakan kegiatan setelah masa panen yang paling membutuhkan banyak tenaga kerja. Tenaga kerja banyak dibutuhkan agar tembakau segera ditata di rigen untuk 
dijemur. Saat ini, aktivitas ngrajang telah dibantu oleh mesin, sehingga mengurangi tenaga kerja yang dibutuhkan. Sebelum adanya mesin rajang, ngrajang dilakukan secara manual menggunakan pisau yang dinamakan gobang. Tenaga kerja yang merajang daun tembakau biasanya laki-laki, karena pekerjaan ini dianggap membutuhkan kekuatan dan stamina tinggi. Catatan lapangan Laily (2016:57) mengenai aktivitas ngrajang sebagai berikut:

"Warga Dusun Lamuk Legok memang
memiliki kebiasaan untuk nyambat (meminta
tolong) tetangga waktu musim rajang.
Karena sudah menjadi kebiasaan, kalaupun
tidak dimintai tolong, dengan sukarela
tetangga akan membantu. Apabila tetangga
bersedia membantu, maka cacak (alat rajang
manual) akan dikirim ke rumah orang
yang meminta tolong. Jika alat rajang tidak
dikirim, bisa diartikan tetangga tersebut
setengah hati untuk membantu. Kalau tidak
sempat mengirim cacak, biasanya akan ada
pemberitahuan."

Ketika tenaga perajang digantikan oleh mesin, kebutuhan tenaga kerja tinggal untuk nganjang saja. Pekerjaan nganjang inilah yang dilakukan dengan sistem royongan oleh perempuan anggota keluarga dan tetangga dekat.

Royongan keluarga perempuan juga dilakukan dalam aktivitas nggulungi. Aktivitas nggulungi adalah menata rajangan tembakau yang sudah kering dan lemas di rigen, menjadi bentuk bulatan-bulatan. Bulatan ini nantinya dimasukkan ke dalam keranjang, yang diistilahkan dengan ngemot. Nggulungi dan ngemot biasanya dilakukan di malam hari menunggu turunnya bun agar rajangan tembakau kering tersebut tidak rusak ketika dimasukkan keranjang.

Gotong royong yang melibatkan keluarga perempuan dalam pekerjaan usahatani sebenarnya merupakan strategi yang dilakukan petani untuk melakukan penghematan pengeluaran keuangan. Pembagian kerja dalam keluarga dibagi menjadi tiga jenis, yaitu produktif, reproduktif, dan sosial kemasyarakatan (Widodo, 2009). Pekerjaan produktif merupakan kegiatan yang menghasilkan uang. Pekerjaan reproduktif adalah kegiatan yang tidak menghasilkan uang, tetapi harus dilaksanakan karena hubungannya dengan kehidupan rumah tangga; misalnya mencuci, memasak, dan mengasuh anak. Pekerjaan sosial kemasyarakatan merupakan pekerjaan yang berhubungan dengan kehidupan bermasyarakat. Perempuan dalam keluarga petani biasanya terlibat intensif dalam pekerjaan reproduktif, dengan selingan pada pekerjaan produktif dan sosial kemasyarakatan. Pelibatan perempuan pada pekerjaan produktif di dunia pertanian berorientasi pada stereotype perempuan yang dianggap lebih teliti dan telaten. Pada kasus usahatani tembakau, perempuan biasanya terlibat pada pekerjaan sortasi yang membutuhkan ketelitian, dan pekerjaan menata rajangan yang membutuhkan ketelatenan.

\section{Melampaui Budaya Srinthil}

Para petani di Desa Legoksari percaya bahwa proses mendapatkan Srinthil tidak terlepas dari empat faktor besar; yakni siti (tanah), wiji (benih), wanci (waktu), dan wahyu (doa/keberuntungan). Salah seorang informan yang merupakan tokoh masyarakat sekaligus budayawan di Desa Legoksari mengatakan:

\begin{abstract}
"Jadi tembakau sini itu dari awal, mulai penanaman, itu yang diperhatikan adalah Siti, Wiji, Wanci dan terakhir Wahyu. Siti ini kaitannya dengan tanah. Kemudian Wiji, petani tembakau Lamuk ini mengedepankan nanti di hasil panen pada kualitas. Kemudian Wanci, kita harus benar-benar mempunyai kalender budidaya tembakau. Pertama, kita mulai pengadaan pupuk kandang, kemudian pengolahan lahan, kemudian lubang tanam, pemupukan, sampai pembersihan rumput atau matun, ini ada time schedule-nya." (Stp, 22 Juli 2017)
\end{abstract}

Adapun yang dimaksud wahyu adalah upaya masyarakat petani tembakau di Legoksari untuk mendapatkan Srinthil dengan berdoa kepada Tuhan YME melalui berbagai ritual dan upacara tradisional.

Semua rangkaian usahatani tembakau Srinthil pada dasarnya menjadi sebuah kearifan lokal; yang menurut dikenal, dipercayai, dan diakui sebagai elemen-elemen penting yang mampu mempertebal kohesi sosial di 
antara warga masyarakat (Haba, 2007, dalam Purwaningsih et al., 2016). Haba mengatakan bahwa terdapat enam signifikansi dan fungsi kearifan lokal: (1) sebagai penanda identitas sebuah komunitas, (2) perekat lintas warga, lintas agama, dan kepercayaan, (3) menjadi sebuah unsur kultural yang hidup di masyarakat, (4) mewarnai kebersamaan sebuah komunitas, (5) mengubah pola pikir dan hubungan timbal balik individu dan kelompok atas dasar kesepakatan bersama, dan (6) mendorong terbangunnya kebersamaan sebagai mekanisme antisipasi potensi merusak, dan sebagai solidaritas komunal.

Apabila Srinthil disebut sebagai budaya, maka tidak salah kiranya apabila tulisan ini mengutip pendapat Edward T. Hall. Salah satu masalah utama dunia saat ini adalah krisis hubungan umat manusia dan perluasan dari hubungan tersebut dengan lembaga (pranata), ide-ide, termasuk di dalamnya hubungan antara individu dan kelompok (Hall, 1960, dalam Liliweri, 2016). Hall berpendapat bahwa jalan keluar dari kekacauan buatan manusia tersebut adalah mengenali dan menerima perbedaan kebudayaan. Srinthil oleh sebagian orang mungkin dianggap sebagai sebuah budaya yang "berbeda". Penyebabnya adalah komoditas tembakau yang merupakan perusak kesehatan. Hall menjelaskan bahwa manusia hendaknya melakukan usaha yang memungkinkan pengembangan alternatif baru, kemungkinan baru, dan jalan baru untuk menggunakan langkah kreatif sebagai perwujudan bakat, yang akhirnya bermanfaat bagisolusiterhadap masalahyang dihadapi oleh keberagaman umat manusia. Sesuai dengan temuan Syani (2016) yang mengatakan tentang perlunya adopsi nilai-nilai kearifan lokal dalam penyebarluasan praktik-praktik pembangunan sehingga mampu mengakomodir beragam kepentingan masyarakat secara harmonis, sehingga tiada pihak yang dikorbankan.

\section{SIMPULAN}

Kearifan lokal usahatani tembakau di Legoksari cukup banyak sebagai bentuk upaya petani untuk mendapatkan wahyu atau anugerah Srinthil. Kearifan lokal yang dimanifestasikan dalam bentuk ritual, tempat tinggal, serta etos kerja ini juga sebagai upaya petani meningkatkan kohesi sosial antarwarga, dan bentuk transmisi nilai antargenerasi. Kearifan lokal tersebut sekaligus menjadi bukti terjaganya sustainabilitas tradisi budaya Jawa melalui usahatani tembakau.

Pemahaman mengenai kearifan lokal usahatani tembakau Srinthil menjadi penting guna mengurangi gegar komunikasi antarbudaya. Pembacaan yang tepat terhadap sebuah budaya akan menciptakan harmoni budaya, dan menjadi solusi atas kekacauan budaya. Pada gilirannya pendekatan kebijakan yang tepat terhadap usahatani tembakau diperlukan, setidaknya untuk mempertahankan kearifan lokal masyarakat petani tembakau.

\section{UCAPAN TERIMA KASIH}

Artikel jurnal ini merupakan bagian dari penelitian yang dibiayai oleh dana hibah Penelitian Disertasi Doktor dari Kementerian Riset, Teknologi, dan Pendidikan Tinggi tahun 2018. Kami juga berterima kasih kepada semua pihak yang telah membantu dalam pengumpulan dan analisis data.

\section{DAFTAR PUSTAKA}

Akbar, A. 2011. “Studi Kearifan Lokal Penggunaan Api Persiapan Lahan: Studi Kasus di Hutan Mawas, Kalimantan Tengah". Jurnal Penelitian Sosial dan Ekonomi Kehutanan 8(3): 211-230.

Alamsyah, A. R. 2011. Hitam-Putih Tembakau. Jakarta: FISIP UI Press.

Bappeda Kabupaten Temanggung 2016. Statistik Kabupaten Temanggung 2016. September. BAPPEDA Kabupaten Temanggung. Temanggung.

Beddu, S., A. Akil, W. W. Osman, dan B. Hamzah. 2014. Eksplorasi Kearifan Budaya Lokal sebagai Landasan Perumusan Tatanan Perumahan dan Permukiman Masyarakat Makassar. Prosiding Temu Ilmiah IPLBI 2014. Universitas Sriwijaya: 7-12.

Creswell, J. W. 2014. Penelitian Kualitatif dan Desain Riset, Memilih di Antara Lima 
Pendekatan. Yogyakarta: Pustaka Pelajar.

Darmastuti, R., A. Bajari, H. S. Martodirdjo, dan E. Maryani. "Gethok Tular, Pola Komunikasi Gerakan Sosial Berbasis Kearifan Lokal Masyarakat Samin di Sukolilo". Jurnal ASPIKOM 3(1): 104118

Dharmawan, A. H. 2007. "Sistem Penghidupan dan Nafkah Pedesaan: Pandangan Sosiologi Nafkah (Livelihood Sociology) Mazhab Barat dan Mazhab Bogor". Sodality: Jurnal Transdisiplin Sosiologi, Komunikasi, dan Ekologi Manusia 1(2): 169-192.

Djono, D., T. P. Utomo, dan S. Subiyantoro. 2012. “Nilai Kearifan Lokal Rumah Tradisional Jawa". Humaniora 24(3): 269-278.

Flick, U. 2007. Designing Qualitative Research. California: SAGE Publications.

Haryanto, S. 2013. Dunia Simbol Orang Jawa. Yogyakarta: Kepel Press.

Hefni, M. 2008. “Local Knowledge Masyarakat Madura: Sebuah Strategi Pemanfaatan Ekologi Tegal di Madura". Karsa 14(2): 131-141.

Herawati, I. 2007. “Makna Simbolik Sajen Slametan Tingkeban". Jantra 2(3): 145-151.

Hidayati, D. 2016. “Memudarnya Nilai Kearifan Lokal Masyarakat dalam Pengelolaan Sumber Daya Air". Jurnal Kependudukan Indonesia 11(1): 39-48.

Kasno, A. 2018. Kearifan Lokal sebagai Upaya Peningkatan Produktivitas Tanah dan Tanaman. Prosiding Konser Karya Ilmiah Tingkat Nasional 2018 Salatiga. Universitas Kristen Satya Wacana: 93104.

Koentjaraningrat. 1964. Masyarakat Desa Masa Kini. Jakarta: Balai Penerbitan Fakultas Ekonomi UI.

Kurniasari, N. dan Reswati, E. 2011. “Kearifan Lokal Masyarakat Lamalera: Sebuah
Ekspresi Hubungan Manusia dengan Laut". Buletin Riset Sosek Kelautan dan Perikanan 6(2): 29-33.

Laily, E. 2016. Srinthil, Pusaka Saujana Lereng Sumbing. Yogyakarta: Pustaka Indonesia.

Liliweri, A. 2016. Konfigurasi Dasar Teori-Teori Komunikasi Antarbudaya. Bandung: Penerbit Nusa Media.

Mamat, H. S., S. R. P. Sitorus, H. Hardjomidjojo, dan A. K. Seta. 2006. "Analisis Mutu, Produktivitas, Keberlanjutan, dan Arahan Pengembangan Usahatani Tembakau di Kabupaten Temanggung, Jawa Tengah". Littri 12(4): 146-153.

Matualage, A. 2011. “Keefektifan Pembelajaran Sosial Kearifan Lokal Budidaya Ubi Jalar di Kalangan Suku Arfak Kabupaten Manokwari". Jurnal Kawistara 1(1): 68-78.

Meliono, I. 2011. “Understanding the Nusantara Thought and Local Wisdom as an Aspect of the Indonesian Education". TAWARIKH: International Journal for Historical Studies 2(2): 221-234.

Pranadji, T. 2009. "Penguatan Kelembagaan Gotong Royong dalam Perspektif Sosio Budaya Bangsa: Suatu Upaya Revitalisasi Adat Istiadat dalam Penyelenggaraan Pemerintahan". Forum Penelitian Agro Ekonomi 27(1): 61-72.

Purwaningsih, E., S. Suwarno dan I. Fibiona. 2016. Kearifan Lokal dalam Tradisi Nyadran Masyarakat Sekitar Situs Liangan. Yogyakarta: Balai Pelestarian Nilai Budaya (BPNB).

Saleh, S. 2014. “Agama, Kepercayaan, dan Kelestarian Lingkungan (Studi terhadap Gaya Hidup Orang Rimba Menjaga Lingkungan di Taman Nasional Bukit Dua Belas (TNBD)Jambi)". Jurnal Kawistara 4(3): 312-322.

Sartini, N. W. 2009. "Menggali Nilai Kearifan Lokal Budaya Jawa Lewat Ungkapan 
(Bebasan, Saloka, Paribasa)". Jurnal Ilmiah Bahasa dan Sastra 5(1): 28-37.

Syani, A. 2016. Strategi dan Pendekatan Nilai Kearifan Lokal Lampung dalam Pemeliharaan Ketenteraman dan Ketertiban Masyarakat Desa. Prosiding Seminar Nasional "Pemberdayaan Masyarakat Menuju Kemandirian Desa" Bandar Lampung. Universitas Lampung: 1-12.

Wagiran. 2012. "Pengembangan Karakter Berbasis Kearifan Lokal Hamemayu Hayuning Bawana". Jurnal Pendidikan Karakter 2(3): 329-339.
Widodo, S. 2009. "Analisis Peran Perempuan dalam Usahatani Tembakau". Embryo 6(2): 148-153.

Yenrizal, Y., A. Rahmat, A. Bajari, dan J. Iskandar. 2015. "Makna Simbolik Sawah di Masyarakat Pedesaan (Tinjauan Komunikasi Lingkungan Pada Masyarakat Semende Darat Tengah Kabupaten Muara Enim Sumatera Selatan)". Jurnal Kawistara 5(3): 287-297. 